\title{
TUDO CONSISTE EM DÍVIDAS, EM CRÉDITOS E EM CONTAS: RELAÇÕES DE CRÉDITO NO BRASIL COLÔNIA; CURITIBA NA PRIMEIRA METADE DO SÉCULO XVIII
}

\author{
Magnus Roberto de Mello Pereira \\ Professor do Departamento de História da Universidade Federal do Paraná, \\ integrante do Centro de Documentação e Pesquisa de \\ História dos Domínios Portugueses - Cedope.* \\ Joacir Navarro Borges \\ Doutorando do Programa de Pós-Graduação em História da \\ Universidade Federal do Paraná, integrante do Cedope.
}

\begin{abstract}
Resumo
A historiografia recente sobre o Brasil colônia tem destruído diversos mitos que herdamos de nossos clássicos, como a noção de autarquia do latifúndio e a de uma acumulação exclusivamente endógena. Hoje é consenso que existiam redes internas de circulação de mercadorias e de acumulação, fortemente ancoradas em redes de crédito/endividamento. A maior parte dos estudos disponíveis sobre o tema aborda as nossas principais praças comerciais, em especial a do Rio de Janeiro. O presente artigo tenta perceber como um pequeno lugar periférico, como a vila de Curitiba, integrava-se a essas redes, a partir da análise de uma fonte inesperada: os termos de audiência dos juízes ordinários da vila. A predominância de processos referentes à cobrança de dívidas permite que sejam visualizados alguns aspectos dessa trama creditícia trançada no centro-sul da colônia.
\end{abstract}

\section{Pallavras-chave}

litigiosidade $\bullet$ juiz ordinário $\bullet$ redes de crédito e endividamento.

\section{Abstract}

Recent historiography on colonial Brazil has destroyed several myths inherited from classic works, such as the notion of large properties functioning in an autarchic way, or the exclusively endogenous accumulation of capital. It is consensual now a days that there were internal networks of merchandise and accumulation strongly anchored in credit/debt networks. The vast majority of studies available on the theme focused the main commercial cities, Rio de Janeiro in particular. This article tries to assess how a small, peripheral place such as the village of Curitiba was integrated in such networks, from the analysis of an unexpected source: the minutes of the village ordinary judges' audiences. The predominance of processes referring to debts overdue allows us to see some aspects of the credit threads put together in the southern part of the Brazilian colony.

\section{Keywords}

debt overdue $\bullet$ ordinary judges $\bullet$ debt/credit networks.

\footnotetext{
*A pesquisa em questão recebeu apoio do CNPQ e da Fundação Araucária.
} 
Em 13 de dezembro de 1766, d. Luís Antônio de Souza Botelho Mourão remeteu uma carta ao conde de Oeiras (futuro marquês de Pombal) apontando para um problema que afligia os moradores da Capitania de São Paulo. Dizia o morgado de Mateus que "passou a tanto excesso o abuso de vender fiado nestes países, que tudo consiste em dívidas, em créditos e em contas, que não tem fim; e as dívidas se perdem muitas e o dinheiro quase nunca se apura." Isto não era uma exclusividade paulista. No período colonial, o crédito funcionou como um mecanismo engenhoso para driblar a recorrente escassez de meios circulantes. Ao lado do ouro em pó e das poucas moedas, circulava uma infinidade de créditos que levaram à formação de grandes redes de endividamento que se ramificavam por todo o Império Português. O crédito permitia a circulação de todo tipo de mercadorias, movimentando o comércio dos dois lados do Atlântico e também nos mais interioranos lugarejos da América portuguesa. Essa função fundamental do crédito parece ter sido estrutural, abarcando todos os níveis sociais e todos os lugares onde houvesse comércio.

As redes creditícias nas quais estavam enredados os moradores dos mais remotos vilarejos paulistas, entre os quais Curitiba, chegavam inclusive a ultrapassar o âmbito comercial português. Fernand Braudel percebeu que, desde meados do século XVI, os mercadores do norte da Europa passaram a controlar boa parte do comércio atlântico a partir do mecanismo de adiantamento de mercadorias aos portos ibéricos. ${ }^{2}$ Diversos estudos já se encarregaram de analisar os tratos e as trajetórias sociais de grandes homens de negócio das principais praças mercantis portuguesas do Antigo Regime. João Fragoso e Manolo Florentino salientaram que o comércio interno do Brasil colônia, entre os séculos XVIII e XIX, não se fazia somente de forma direta, mas principalmente por meio da "cadeia de adiantamento/endividamento". ${ }^{3}$ A partir de sua participação no comércio ultramarino, os mercadores do Rio de Janeiro supriam a praça com produtos fundamentais para o mercado interno, repassando-os para terceiros, em geral também comerciantes de outras praças da colônia, que se encarregavam em vendê-los diretamente. Esse sistema subordinava os comerciantes menores

\footnotetext{
Documentos interessantes para a história e costumes de São Paulo, v. 73, p. 88.

BRAUDEL, Fernand. Reflexões sobre a história. São Paulo: Martins Fontes, 1992, p. 312.

3 FRAGOSO, João; FLORENTINO, Manolo. O arcaísmo como projeto: mercado atlântico, sociedade agrária e elite mercantil em uma economia colonial tardia. Rio de Janeiro: Sette Letras, 1998, p. 89-100. FRAGOSO, João. Homens de grossa aventura. Rio de Janeiro: Civilização Brasileira, 2000, p. 241-252.
} 
aos comerciantes cariocas, garantindo a participação destes no comércio das diversas praças do centro-sul da colônia. Essa forma de atuação lhes garantia também o controle da estrutura mercantil do centro-sul da América portuguesa. O historiador Antônio Jucá de Sampaio é quem melhor tem caracterizado o processo de formação de cadeias de endividamento no Brasil colônia. Segundo ele, "podemos dizer que todo grande comerciante produz, a partir de si, uma cadeia de endividamento que coincidia, em grande parte com sua rede de relações mercantis. Em outras palavras, relações mercantis envolviam sempre, ou quase, a criação de relações de crédito."4

$\mathrm{O}$ leque de atividades e investimentos dos negociantes do Antigo Regime era relativamente amplo, compreendendo prédios urbanos, bens comerciais, escravos, bens rurais e atividades creditícias (dívidas ativas e dívidas passivas). Dos itens citados, as dívidas ativas tiveram papel preponderante na formação das fortunas daqueles mercadores. Analisando a composição média das fortunas dos comerciantes do extremo sul, Helen Osório observou que os itens dívidas ativas $(27,4 \%)$ e prédios urbanos $(22,4 \%)$ definiam seus perfis de negócios. Esta tendência pode ser observada - com algumas variações - também na elite mercantil do Rio de Janeiro, Buenos Aires e Lisboa. Nesta última praça, as dívidas ativas correspondiam a 52,2\% dos patrimônios e os bens de raiz vinham em segundo lugar, com $17,61 \%{ }^{5}$

$\mathrm{O}$ acima exposto resume em largos traços o que se tem avançado no estudo do grande comércio no Antigo Regime. Todavia, ainda são poucos os trabalhos focados sobre os lugares menores e mais periféricos. Parte substantiva da responsabilidade pela limitação de tais estudos tem sido a ausência de fontes. Para Curitiba, tivemos a sorte de encontrar alguns livros de notas dos juízes ordinários do século XVIII, os quais se demonstraram excelentes fontes para o estudo do endividamento no período. Livros desta natureza são raros em nossos arquivos e até onde foi possível alcançar não foram utilizados para o

4 SAMPAIO, Antonio C. Jucá de. Os homens de negócio do Rio de Janeiro e sua atuação nos quadros do Império Português (1701-1750). In: FRAGOSO, João; BICALHO, Maria Fernanda; GOUVÊA, Maria de Fátima (orgs.). O antigo regime nos trópicos: A dinâmica imperial portuguesa (séculos XVI -XVIII). Rio de Janeiro: Civilização Brasileira, 2001, p. 104. Ver, também, SAMPAIO, Antonio C. Jucá de. Crédito e circulação monetária na colônia: o caso fluminense, 1650-1750. In: Anais do V Congresso Brasileiro de História Econômica. http:// www.abphe.org.br/congresso2003/Textos/Abphe_2003_75.pdf.

5 OSÓRIO, Helen. Comerciantes do Rio Grande de São Pedro: formação, recrutamento e negócios de um grupo mercantil da América portuguesa. Revista Brasileira de História. São Paulo, v. 20, n. 39, 2000, p. 114-115. 
estudo de relações creditícias. No entanto, o seu uso para o estudo do crédito é quase obrigatório, pois nesses registros predominavam largamente processos de cobrança judicial de dívidas.

O presente estudo é o resultado da analise dos registros das audiências de juízes ordinários de Curitiba, entre 1731 e 1752. Tais balizas cronológicas são resultado de um fato inapelável: os manuscritos disponíveis cobrem apenas esse intervalo. Do total de processos em tramitação no período, 1.248 referiam-se a cobranças. Assim, nada menos que $85 \%$ de todos os processos arbitrados pelos juízes ordinários estiveram ligados às demandas creditícias. Tal evidência permite avançar uma primeira constatação, ainda pouco explorada pela historiografia brasileira: o juízo local era um espaço privilegiado para a legitimação e a cobrança de dívidas das mais diversas espécies. A maioria dos processos por dívidas seguia dois padrões: reconhecimento de sinal e ações d'alma. $\mathrm{O}$ reconhecimento de sinal acontecia quando o credor comparecia perante o juiz ordinário e requeria a presença do devedor para que reconhecesse o seu sinal ou assinatura em um crédito escrito, legitimando a dívida perante a justiça. As ações d'alma se davam quando o credor requeria, nas audiências judiciais, que o devedor jurasse por sua alma se devia ou não uma determinada quantia.

Apesar da quantidade expressiva de processos envolvendo dívidas no juizado ordinário, é necessário reconhecer que elas representam uma ínfima parcela dos vínculos de créditos que permearam a sociedade curitibana setecentista. As relações de haver e dever extrapolavam a documentação judiciária, haja vista que é de se supor que a maioria dos empréstimos era saldada sem interveniência judicial. Os registros de concessão de créditos de valores os mais diversos também podem ser encontrados nos livros de notas do tabelionato local. Como bem notou Raphael Santos, muitos créditos podiam ser concedidos tendo como garantia apenas a confiança na palavra dada, pois, na época, o termo "crédito" vinculava-se à noção de "confiança". Assim, como solução para a precária circulação monetária, aquela sociedade "efetivou como uma nova moeda, no conjunto das transações diárias, a palavra escrita ou falada, que coexistiu com a circulação de outras moedas, principalmente o ouro em pó.”’

O padrão de endividamento na vila de Curitiba parece ter refletido, num nível micro, o que ocorria nas grandes praças mercantis do Antigo Regime. A formata-

6 SANTOS, Raphael Freitas. Juramentos da alma; Indícios da importância da palavra no universo colonial mineiro. In: Anais da И Jornada Setecentista. Curitiba: Aos Quatro Ventos, 2006, p. 491. 
ção de redes de crédito e endividamento da maioria das pequenas localidades do Brasil colônia no século XVIII devia seguir um padrão parecido ao da realidade curitibana. Sheila de Castro Faria demonstrou esse padrão quando analisou o comércio e o crédito da região de Campos dos Goitacases no norte fluminense: relativa pobreza dos pequenos comerciantes com montantes relativamente modestos, generalizado endividamento, ação de usurários, estabelecimento de redes de clientela e ramificação dos negócios. ${ }^{7}$ É importante lembrar que, dado o caráter geral do endividamento nessa sociedade, mesmo indivíduos de extratos mais baixos, como artesãos, eram frequentemente credores de outrem, por serviços realizados e não pagos. Nesses casos, o juízo ordinário dividia com a almotaçaria o espaço de mediação judicial entre credores e devedores. ${ }^{8}$

\section{Prestamistas e tomadores}

As redes de crédito e endividamento tinham tanto um caráter local, quanto ramificações que se alongavam por todo o centro-sul da colônia e podiam, no caso dos comerciantes de grosso trato, chegar até a metrópole e, daí, à Europa do norte. A pequena vila de Curitiba era apenas mais um ponto no interior das muitas ramificações periféricas da rede de crédito e endividamento típica da economia da época. Muitas pessoas envolvidas nos processos de cobrança de dívidas em Curitiba certamente faziam parte daquela "multidão de pequenos e médios mercadores, majoritários numericamente, mas com limitado raio de alcance mercantil, sendo a sua atuação marcada pela ocasião conjuntural." ${ }^{9}$

\footnotetext{
7 FARIA, Sheila de Castro. A colonia em movimento. Rio de Janeiro: Nova Fronteira, 1998, p. 178 186. A caracterização dos comerciantes do Brasil colônia sugere um quadro geral semelhante. Ver, por exemplo, FURTADO, Júnia Ferreira. Homens de negócio: a interiorização da metrópole e do comércio nas Minas setecentistas. São Paulo: Hucitec, 1999. VENÂNCIO, Renato Pinto e FURTADO, Júnia Ferreira. Comerciantes, tratantes e mascates. In: DEL PRIORE, Mary (org.). Revisão do paraíso; Os brasileiros e o Estado em 500 anos de história. Rio de Janeiro: Campus, 2000. CHAVES, Cláudia Maria das Graças. Perfeitos negociantes: mercadores nas Minas setecentistas. São Paulo: Anna Blume, 1999. BORREGO, Maria Aparecida Menezes. A teia mercantil: negócios e poderes em São Paulo colonial (1709-1765). Tese de Doutorado, História, USP, 2007.

8 Ver PEREIRA, Magnus Roberto de Mello e NICOLLAZI JR., Norton. Audiências e correições dos almotacés; Curitiba, 1737 a 1828. Curitiba: Aos Quatro Ventos, 2003. Para uma abordagem mais geral da atuação dos almotacés, ver PEREIRA, Magnus Roberto de Mello. Almuthasib; considerações sobre o direito de almotaçaria nas cidades de Portugal e suas colônias. Revista Brasileira de História. São Paulo, v. 21, n. 42, 2001, p. 365-395. e O direito de almotaçaria; considerações sobre o direito urbano no mundo lusitano In. História dos municípios: Administração, eleições, finanças. Funchal: Centro de Estudos de História do Atlântico, 2001, p. 145-166.

9 FRAGOSO. Homens de grossa aventura, op. cit., p. 241.
} 
A maioria das cobranças judiciais era de valores pequenos, ou seja, havia um generalizado microendividamento. Os grandes prestamistas e os grandes tomadores de empréstimos eram relativamente poucos, indicando uma forte concentração de renda. Dos 1.248 processos envolvendo relações creditícias junto ao Juízo Ordinário de Curitiba, entre 1731 e 1752, somente 983 mensuraram os valores cobrados em mil-réis, que totalizaram um montante de 31:642\$316. Foram cobradas ainda 42 dívidas em oitavas de ouro em pó que totalizaram 860 oitavas. Se nos fiarmos nas avaliações de Roberto C. Simonsen, ${ }^{10}$ podemos considerar um valor médio de $1 \$ 200$ para cada oitava de ouro em pó, no período analisado, somando um total aproximado de 1:032\$000 em oitavas de ouro.

Foram feitas 265 cobranças de dívidas que não puderam ter seus valores estipulados. Cerca de $5 \%$ dos processos de cobrança de dívidas simplesmente não enunciaram o seu montante, às vezes referindo-se a "certa quantia de dinheiro" ou "jurar pelo valor de um crédito", sem especificar valores. Nos outros processos, foram feitas cobranças de toda sorte de bens característicos daquela sociedade. Foram cobrados tecidos, objetos, produtos e animais, que, às vezes, traziam seus valores, mas outras tantas vezes não. Os bens com valores expressos em réis, oitavas de ouro, patacas, vinténs ou cruzados foram incorporados nos montantes discriminados acima.

Diversos bens cobrados em juízo eram artigos de primeira necessidade na vida dos habitantes da vila de Curitiba no século XVIII. Nesta categoria estão incluídos os mantimentos, arroz, feijão, milho, farinha, trigo, peixes e até a aguardente, se considerarmos seus múltiplos usos, inclusive medicinais. Aparecem também as casas, taperas e seus consertos. Outros bens, como armas de fogo, sela, cochonilha, cangalha, cavalos, potros, éguas, gado vacum, bestas muares, além de serviços prestados na condução de todo tipo de gado muar, vacum e cavalar, estão relacionados ao negócio de tropa, importante atividade econômica da localidade, que ganhou maior desenvoltura a partir da abertura do caminho do Viamão no início da década de 1730. A mão-de-obra escrava também comparece, através da cobrança dos valores de um negro e uma negra.

Além dos bens de maior necessidade, também surgiam nas audiências cobranças de artigos ligados à aparência pessoal, tais como: camisas de olanda, ${ }^{11}$

\footnotetext{
${ }^{10}$ SIMONSEN. Roberto Cochrane. História econômica do Brasil (1500-1820). São Paulo: Companhia Editora Nacional, 1978, p. 283. Trata-se apenas de uma generalização. As flutuações da cotação do ouro podem ser vistas em ZEMELLA, Mafalda P. O abastecimento da Capitania das Minas Gerais no século XVIII. São Paulo: Ed. Hucitec-Edusp, 1990, p. 133.

${ }^{11}$ Era o termo que se utilizava para designar tecidos de linho. Raphael Bluteau define olanda
} 
casacas, calções, pares de meias finas, pares de brincos de ouro, pentes e cabeleiras. Embora minoritária, a presença desses bens no rol de cobranças da Justiça Ordinária de Curitiba assinala a importância social que os trajes tinham nas sociedades do Antigo Regime. Além disso, aquela era uma economia de reaproveitamento, na qual o comércio de roupas usadas - inclusive dos falecidos - era muito frequente, pois as roupas representavam um dos bens mais comuns encontrados nos inventários da época.

Muitos dos autores dos processos que cobravam dívidas eram pequenos lojistas locais. Em 21 de julho de 1752, Antonio de Oliveira de Assunção cobrou a Paulo da Rocha a quantia de $5 \$ 120$ "de fazenda que lhe comprara na sua loja."12 O mesmo Antonio de Oliveira compareceu - ele próprio ou seus procuradores - em seis outras ocasiões perante os juízes ordinários cobrando um montante total de 226\$722, uma quantia bastante razoável para os padrões curitibanos. Além disso, cobrou dez potros de Miguel Rodrigues Ribas, um dos potentados locais. Antonio de Oliveira é um legítimo representante dos lojistas que atuaram como uma das fontes dispensadoras de crédito na vila de Curitiba, pois, como apontou Fernand Braudel, "a loja é a permuta adequada de crédito, pois o lojista recebe sua mercadoria a crédito e vende-a a crédito. Neste ponto, estende-se através da troca toda uma sequência de dívidas e de créditos." ${ }^{13}$

Além da concentração do dinheiro nas mãos de poucos e a consequente escassez de moeda sonante, as sociedades do Antigo Regime eram majoritariamente agrárias e o calendário de safras e entressafras fazia do crédito um instrumento fundamental para sustentar as demandas materiais cotidianas entremeio aos ciclos agrícolas. $\mathrm{O}$ crédito também desempenhava o papel de mecanismo de subordinação do devedor ao credor, criando ligações pessoais e mercantis fortes e duradouras entre as partes.

\section{0 mercado de crédito em Curitiba}

Os processos do Juízo Ordinário de Curitiba apontam para uma generalizada rede de crédito / endividamento. O gráfico 1 demonstra que, entre meados

como "certa lençaria de várias castas. Há olanda fina, e fina atacada, ordinária, grossa, riscada e frisada, larga e olanda dita seda." BLUTEAU, D. Raphael. Vocabulário portuguez e latino. Lisboa: Officina de Pascoal da Sylva, 1716.

${ }^{12}$ Biblioteca da Câmara Municipal de Curitiba (doravante citada como BCMC). Livro de audiências dos juizes ordinários, 1751-1752, fl. 99v.

${ }^{13}$ BRAUDEL, Fernand. A dinâmica do capitalismo. Rio de Janeiro: Rocco, 1987, p. 22. 
da década de 1730 e o início da década de 1750, ocorreram ciclos regulares de pico-vale-pico-vale no número de processos e requerimentos. A comparação entre o período de 1731 a 1736 e o período de 1736 a 1751, revela que o primeiro intervalo de tempo foi caracterizado pelo progressivo aumento da atividade judiciária, demonstrado na elevação progressiva do número de audiências, processos e requerimentos, que atingiram o pico em 1736, para então encontrarem um forte recuo e uma certa estabilização no segundo quinquênio para novamente subir no início da década de 1740.

\section{Gráfico 1}

Distribuição de audiências, processos e requerimentos entre 1731 e 1752*

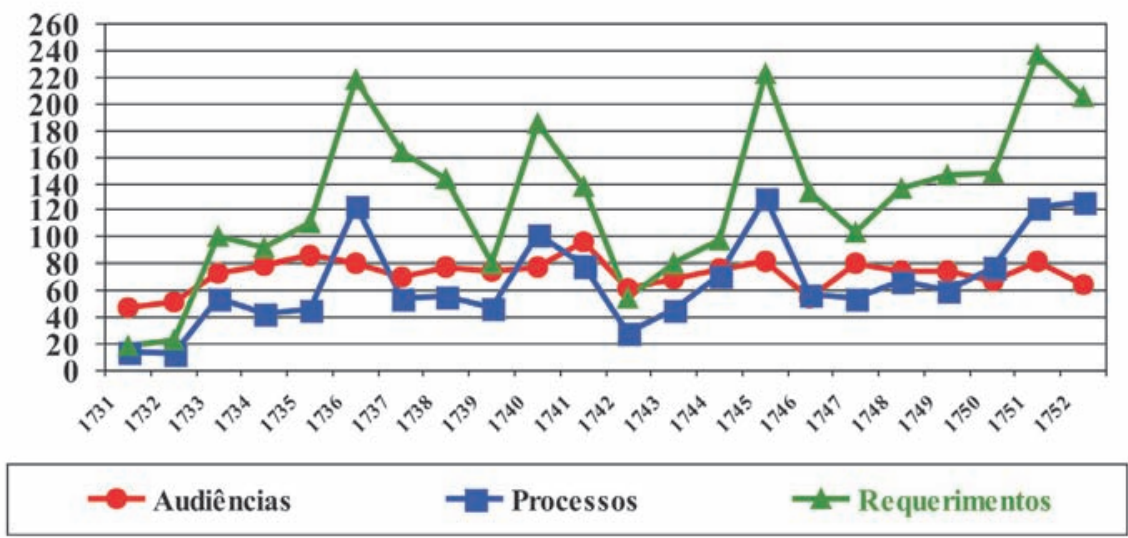

* Elaborado a partir de dados retirados dos oito volumes dos Livros de audiências dos juízes ordinários, abrangendo o período de 1731 a 1752.

Na década de 1740, novo e significativo recuo aconteceu em 1742 para então atingir novo pico em 1745, para novamente recuar em 1747 e entrar numa linha ascensional até 1752. Infelizmente, não dispomos de um período maior de documentação que nos permita avaliar com precisão se estes ciclos continuaram a se repetir ou foi apenas uma coincidência do período analisado.

Uma hipótese possível para explicar o comportamento dos ciclos judiciários pode ser encontrada no fato de que o aumento e diminuição do número de processos reflitam o ciclo de litigiosidade próprio da população local. Se levarmos em conta que a maioria dos processos referia-se ao endividamento da população residente na vila e em seu termo, podemos inferir que o ciclo processual refle- 
tia o ciclo da capacidade de crédito e endividamento dessa mesma população. Nesse sentido, é possível que esses ciclos judiciários tenham acompanhado os ciclos econômicos da vila, pois chama a atenção o fato de ter havido um forte e repentino crescimento da demanda judiciária no período de 1731 a 1736 , concomitantemente à abertura do caminho do Viamão e ao estabelecimento do registro da Vila de Curitiba, cujo surgimento estava ligado à demanda de gado em São Paulo, Rio de Janeiro e Minas Gerais. ${ }^{14}$ Este período também assinalou o maior ciclo de crescimento da produção de ouro na colônia.

A tabela 1 possibilita cruzar os dados relativos ao número de processos e os montantes totais das dívidas em réis e em oitavas de ouro. Tomando como exemplo a comparação de anos isoladamente, percebemos que não há uma relação direta entre a diminuição do número de processos e diminuição na mesma proporção dos montantes cobrados. Pelo contrário, em 1737, o montante total das dívidas cresceu em relação a 1736, apesar da grande diminuição do número de processos. Isso se deveu à quase triplicação do valor médio das dívidas cobradas em 1737 em relação ao ano de 1736.

O período de 1742 a 1752 também configurou altos e baixos nos processos que não se refletiram necessariamente nos montantes. Correspondendo a um vale no gráfico 1, o ano de 1742 foi um exemplo, pois foi o ano com menor número de processos de dívidas em réis (apenas 17), mas os valores médios cobrados foram os mais altos de todo o período, tanto em réis $(114 \$ 774)$, como em oitavas de ouro (81). $\mathrm{O}$ ano de 1745 corresponde ao maior pico de processos de todo o período (116), só igualado por 1752. No entanto, quando comparamos os montantes dos dois anos notamos uma discrepância de quase $75 \%$ entre eles.

\footnotetext{
${ }^{14}$ Apenas para citar alguns exemplos do florescente comércio de gado entre Curitiba e São Paulo, Minas Gerais e Rio de Janeiro. Em março de 1737, José Gonçalves de Siqueira requereu ao juiz e mais oficiais da Câmara de Curitiba uma carta de guia "para tirar de suas fazendas que tem nos campos Gerais distrito desta vila trezentas cabeças de gado vacum para as levar para as partes das Minas Gerais." (BCMC. Livro de avulsos, v. 2, fl. 16). Em 1740, a Câmara de Curitiba recebeu um pedido de "Miguel Pinto Ribeiro morador desta vila e nela contratador dos dízimos que ele pretende fazer viagem para São Paulo e Rio de Janeiro ou para donde se oferecer, e leva em sua companhia uma boiada de quatrocentas até quinhentas rezes de gado vacum.” (BCMC. Livro de avulsos, v. 2, fl. 20).
} 


\section{Tabela 1}

Relação entre o número de processos e os montantes das dívidas 1731-1752

\begin{tabular}{|c|c|c|c|c|c|c|}
\hline Ano & $\begin{array}{c}\mathrm{N}^{\circ} \mathrm{de} \\
\text { processos de } \\
\text { dívidas em } \\
\text { réis* } \\
\end{array}$ & $\begin{array}{l}\text { Montante } \\
\text { total (réis) }\end{array}$ & $\begin{array}{l}\text { Média em } \\
\text { réis }\end{array}$ & $\begin{array}{l}\text { N. }{ }^{\circ} \text { de proces- } \\
\text { sos de dívidas } \\
\text { em oitavas de } \\
\text { ouro em pó }\end{array}$ & $\begin{array}{c}\text { Montante } \\
\text { total em } \\
\text { oitavas de } \\
\text { ouro em pó }\end{array}$ & $\begin{array}{c}\text { Média em } \\
\text { oitavas de } \\
\text { ouro em pó }\end{array}$ \\
\hline 1731 & 4 & $82 \$ 600$ & $16 \$ 520$ & 2 & 24 & 12 \\
\hline 1732 & 1 & $9 \$ 000$ & $9 \$ 000$ & - & - & - \\
\hline 1733 & 12 & $211 \$ 490$ & $17 \$ 624$ & - & - & - \\
\hline 1734 & 22 & $646 \$ 870$ & $29 \$ 403$ & - & - & - \\
\hline 1735 & 27 & $496 \$ 980$ & $18 \$ 400$ & 1 & $1 \frac{1 / 2}{2}$ & $1 \frac{1 / 2}{2}$ \\
\hline 1736 & 67 & $809 \$ 734$ & $12 \$ 080$ & - & - & \\
\hline 1737 & 25 & $899 \$ 300$ & $35 \$ 972$ & 2 & 12 & 6 \\
\hline 1738 & 24 & $234 \$ 800$ & $9 \$ 783$ & 1 & $81 / 2$ & $81 / 2$ \\
\hline 1739 & 35 & $1: 613 \$ 640$ & $46 \$ 104$ & - & - & - \\
\hline 1740 & 48 & $766 \$ 170$ & $15 \$ 961$ & 14 & $953 / 4$ & $63 / 4$ \\
\hline 1741 & 52 & $1: 536 \$ 755$ & $29 \$ 559$ & 3 & $136^{1 / 4}$ & $451 / 2$ \\
\hline 1742 & 17 & $1: 951 \$ 170$ & $114 \$ 774$ & 1 & 81 & 81 \\
\hline 1743 & 31 & $1: 900 \$ 672$ & $61 \$ 312$ & 2 & 15 & $7 \frac{1}{2}$ \\
\hline 1744 & 58 & $2: 754 \$ 382$ & $47 \$ 489$ & 2 & $301 / 4$ & 15 \\
\hline 1745 & 116 & $4: 254 \$ 494$ & $36 \$ 674$ & 4 & 191 & $473 / 4$ \\
\hline 1746 & 36 & $1: 449 \$ 170$ & $40 \$ 254$ & 0 & - & - \\
\hline 1747 & 42 & $1: 227 \$ 309$ & $29 \$ 221$ & 2 & 43 & $21 \frac{1}{2}$ \\
\hline 1748 & 467 & $1: 448 \$ 805$ & $30 \$ 825$ & 3 & $108 \frac{1}{2}$ & 36 \\
\hline 1749 & 42 & $1: 188 \$ 772$ & $28 \$ 488$ & - & - & - \\
\hline 1750 & 55 & $2: 946 \$ 016$ & $53 \$ 563$ & 4 & $81 \frac{1 / 2}{2}$ & $201 / 2$ \\
\hline 1751 & 106 & $3: 662 \$ 417$ & $34 \$ 551$ & 1 & 32 & 32 \\
\hline 1752 & 116 & $1: 408 \$ 991$ & $12 \$ 146$ & - & - & - \\
\hline Total & 983 & $31: 642 \$ 316$ & $32 \$ 189$ & 42 & 860 & $201 / 2$ \\
\hline
\end{tabular}

* Considerados apenas os processos valorados em réis.

** Considerados apenas os processos valorados em oitavas de ouro em pó.

Contudo, se dividirmos e compararmos os 22 anos do período 1731-1752 em dois períodos de 11 anos cada, os resultados podem apontar em outra direção. A média geral das dívidas para todo o período foi de 32\$189. No período de 1731 a 1741, apenas dois anos (1737 e 1739) superaram essa média. No período de 1742 a 1752, sete dos onze anos ficaram acima da média geral. No período de 1731 a 1741, foram cobradas 317 dívidas em réis e 23 em oitavas de ouro, ao passo que, no período de 1742 a 1752, esse número aumentou para 666 dívidas em réis e diminuiu um pouco para 19 em oitavas de ouro, o que representou um 
aumento de mais de $100 \%$ no número total de processos por dívidas. Todavia o montante cobrado entre 1731 e 1741 foi de 7:406\$939 e 278 oitavas, enquanto que, no período de 1742 a 1752, o montante mais que triplicou em réis, somando 24:235\$377 e mais que duplicou em oitavas, somando 582 oitavas.

Podemos afirmar, então, que apesar do grande aumento dos montantes cobrados em réis e em oitavas de ouro no período 1742-1752, isso não significou um aumento do número de processos por dívidas na mesma proporção, haja vista que houve uma tendência de aumento dos valores médios cobrados, indicando também uma continuação da tendência à concentração da riqueza em um patamar mais alto.

Houve um formidável crescimento da produção de ouro na colônia, entre 1701 e 1760, atingindo seu pico máximo entre 1741 e 1760. Nesse contexto, muitos colonos viram a possibilidade de ter acesso ao ouro mais abundante que circulava pelos caminhos brasileiros. Muitos tropeiros foram atraídos para a região e muitos habitantes da vila de Curitiba passaram a ganhar a vida conduzindo tropas. Prova disso são os processos de cobrança de pagamento pela condução de tropas levados ao Juízo Ordinário.

Quando analisamos os montantes das dívidas cobradas em réis, percebemos que tais montantes quase quadruplicaram quando comparamos a década de 1731-1740 à década de 1741-1750. Se considerarmos os quase doze anos entre 1740 e 1752, os montantes quase quintuplicaram quando comparados à década de 1731-1740. Portanto, a curva de crescimento do endividamento na vila de Curitiba acompanhou a curva de crescimento da produção de ouro na colônia.

\section{Crédito e sazonalidade econômica anual}

A economia curitibana - baseada na agricultura e no pastoreio - estava muito atrelada aos ritmos naturais. Periodicamente, conforme determinava a legislação, os juizes ordinários faziam audiências públicas, ficando à espera de que os litigantes aparecessem para abrir novos processos ou dar sequência a outros já em andamento. Por vezes, os juízes ficavam à espera sem que ninguém aparecesse para requerer em juízo. Quando observamos as variações anuais dos números de requerimentos apresentados ao Juízo Ordinário, percebemos que eles refletem a sazonalidade econômica da região. Embora, na média, o mês de outubro tenha tido maior número de audiências, o número de audiências em que houve requerimentos foi de apenas $67,5 \%$, bastante aquém do mês de junho, que teve a menor média de audiências, mas teve o maior número de audiências em que houve requerimentos (88\%). 
É sintomática também a sensível diminuição da quantia de requerimentos entre os meses de agosto a fevereiro (exceto novembro), sendo dezembro o mês de menor ocorrência. De fato, em dezembro, devido às comemorações natalícias, muitas vezes os juízes terminavam o ano judiciário por volta do dia vinte, publicando férias até o dia de reis. Foi o mês que registrou o menor quantitativo de audiências, o que, certamente, também contribuiu para a diminuição do número de requerimentos. Além disso, as audiências realizadas em dezembro - fim do ano judiciário e época das festas natalícias - em geral eram pouco disputadas pelos litigantes, sendo geralmente ocupadas pela publicação das sentenças e despachos dos juízes, haja vista que suas judicaturas estavam a findar e precisavam colocar termo nos processos iniciados sob seu arbítrio.

\section{Gráfico 2}

Média das audiências e requerimentos mês a mês entre 1731 e 1752

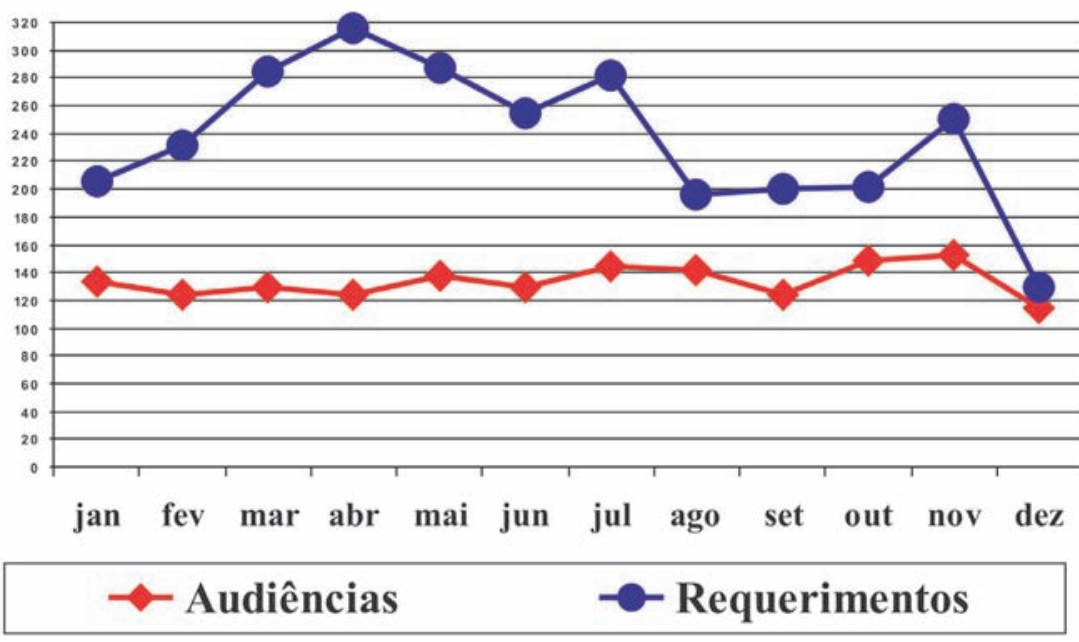

É possível que o súbito aumento do número de requerimentos no mês de novembro represente o desejo das partes envolvidas de terminar os processos judiciários já iniciados antes do recesso judiciário de dezembro, evitando, assim, que a ação corresse o risco de se estender para o ano subsequente.

Os meses do final do inverno, primavera e verão eram também os momentos privilegiados para o amanho agropastoril, quando se retomava o ciclo anual da 
agricultura, o preparo da terra, a semeadura e o cuidado com a lavoura até a colheita. Em 19 de agosto de 1748, diversos moradores da vila fizeram petição para que fossem exterminados os porcos soltos, pois estavam destruindo "suas lavouras especialmente dos trigos que no presente tempo estão nascidos de pouco". ${ }^{15}$ Numa audiência judicial ocorrida em 12 de agosto de 1744, o autor Manoel Dias Collaço acusou Sebastião dos Santos Pereira de lhe ter provocado prejuízo, pois suas criações invadiram e destruíram a roça do autor. O réu respondeu que suas vacas não poderiam ter feito tamanho estrago porque já havia o autor "há muitos dias colhido milho da sua roça por ser tempo, como todos os mais moradores". ${ }^{16}$

Saint-Hilaire, quando de sua passagem pela região de Curitiba e Campos Gerais, afirmou que a semeadura do trigo na região era efetuada em junho, o tabaco era plantado em julho e agosto, o plantio do arroz era feito em setembro e o do feijão em outubro com colheita em janeiro. ${ }^{17}$ De fato, o período de agosto a outubro (queda nos requerimentos) coincide com o período de plantio, colheita e cuidado das principais lavouras da região.

As atividades agropastoris certamente levavam muitos litigantes a afastarem-se momentaneamente da sede da vila, assim como algumas vezes os próprios juízes ordinários se ausentaram para cuidar de seus interesses agrários. Em 28 de novembro de 1738, o juiz ordinário Joseph Dias Cortes mandou publicar "férias de um mês em razão de tratar de suas lavouras por não se perderem suas plantas e lavouras". ${ }^{18}$ Essas férias "para colhimento do pão e vinho" eram previstas nas Ordenações Filipinas. ${ }^{19}$ Da mesma forma, em 31 de dezembro de 1746, os oficiais da Câmara "mandaram declarar que a causa de não terem feito mais vereança foi por causa de não terem juiz presidente por estes se acharem ausentes nos seus sítios e lavras tendo chamado ao juiz Pedro Antonio o vereador Joam Gonçalves Teyxeira varias vezes em sua própria pessoa e mandando-lhe vários recados e por esta razão se retardaram as faturas". ${ }^{20}$

\footnotetext{
${ }^{15}$ Boletin do Archivo Municipal de Curitiba (doravante citado como BAMC), v. XIX, p. 37.

${ }^{16}$ Arquivo Público do Paraná. Autuação de petição apresentada a mim escrivão por parte de Sebastião dos Santos Pereira. JP0819, fl. 5v.

${ }^{17}$ SAINT-HILAIRE. Auguste. Viagem pela Comara de Curitiba.Curitiba: Clichepar, 1995, p. 28-30.

${ }^{18}$ BCMC. Livro de audiências dos juizes ordinários, 1738-1743, fl. 19v.

${ }^{19}$ Ordenações Filipinas, v. III. Lisboa: Fundação Calouste Gulbenkian, 1985, p. 582.

${ }^{20}$ BAMC, v. XVIII, p. 79.
} 
Além dos trabalhos agrícolas, o desenvolvimento do tropeirismo na região de Curitiba também pode ter contribuído para esse ciclo anual de audiências. Vindas do Continente de São Pedro (Rio Grande do Sul), a maior parte das tropas chegava à região dos Campos Gerais em novembro e dezembro, época mais adequada para o início da invernagem. No final da primavera e durante o verão, os animais poderiam passar mais tempo em repouso desfrutando de melhores pastos. O gráfico 2 mostra um súbito aumento do número de requerimentos em novembro, que também pode estar ligado às demandas desses tropeiros recém chegados. Além disso, os tropeiros que seguiam antecipadamente para o sul, nos meses de agosto, setembro e outubro, poderiam escolher os melhores animais e obter mais lucro, o que também coincide com a queda no número de requerimentos nos mesmos meses.

O período chuvoso dos meses de janeiro, fevereiro e março não era adequado às viagens, o que prendia momentaneamente esses homens "volantes" à região, havendo uma escalada no número de requerimentos junto ao Juízo Ordinário de Curitiba. Abril, época em que as tropas, descansadas e engordadas, iniciavam seu movimento rumo às feiras de Sorocaba, representou o pico no número de requerimentos. Era o momento em que a engrenagem da economia tropeira se movimentava. Era a vez do comércio, da movimentação do dinheiro e das mercadorias, momento em que os tropeiros se abasteciam de gêneros para a viagem que se iniciava e os comerciantes realizavam seus melhores negócios. Como a maioria dos processos da justiça ordinária se referia às demandas creditícias, é certo que esse movimento tropeiro tenha influenciado diretamente o aumento do número dos requerimentos.

É digna de nota, a queda no número de requerimentos nos meses de maio e junho, período em que os tropeiros se ausentavam para as partes de Sorocaba. Novo aumento era registrado em julho, período em que estavam retornando de suas viagens de negócios para retomar o ciclo anual do tropeirismo a partir de agosto. É possível que, em julho, esses homens estivessem fazendo seus requerimentos para quitar ou cobrar suas dívidas na região de Curitiba, antes que se pusessem novamente em marcha rumo ao Viamão. Tudo indica a existência de uma sazonalidade econômica que influenciava diretamente o ciclo de crédito e endividamento de parte da população do termo da vila de Nossa Senhora da Luz dos Pinhais de Curitiba no século XVIII. 


\section{Os valores das dívidas e a concentração de riqueza}

Os valores cobrados no Juízo Ordinário da vila de Curitiba variaram em extremos, desde 0\$160 até 1:314\$000. A tabela 2 demonstra que os valores extremos representaram poucos processos. Apenas 3,9\% deles foram relativos a dívidas entre $0 \$ 100$ e $0 \$ 999$ réis, valores muito pequenos que, em sua maioria, eram negociados e pagos diretamente entre as partes, sem a necessidade de apelar aos recursos judiciários locais, pois as custas processuais desestimulavam tal expediente. Prova disso é o rito sumário seguido pelo juiz nesses processos, nos quais, se o réu não comparecesse logo na primeira audiência para fazer o seu juramento, o juiz o condenava na mesma audiência não dando a ele a oportunidade de ficar esperado para comparecer na próxima.

Tabela 2

Relação percentual entre os processos e os montantes das dívidas - 1731-1752

\begin{tabular}{|l|l|r|r|r|r|}
\hline \multicolumn{1}{|c|}{ Período } & \multicolumn{1}{|c|}{$\begin{array}{c}\text { Intervalos de valor } \\
\text { em réis }\end{array}$} & $\begin{array}{c}\text { Número } \\
\text { de } \\
\text { proces- } \\
\text { sos por } \\
\text { dívidas }\end{array}$ & $\begin{array}{c}\text { Percentual } \\
\text { aprox. dos } \\
\text { processos }\end{array}$ & $\begin{array}{c}\text { Montantes } \\
\text { das dívidas } \\
\text { em réis }\end{array}$ & $\begin{array}{c}\text { Percentual } \\
\text { aprox. dos } \\
\text { montantes }\end{array}$ \\
\hline $1731-1752$ & De $0 \$ 100$ a $0 \$ 999$ & 38 & 3,9 & $23 \$ 430$ & 0,075 \\
\hline $1731-1752$ & De $1 \$ 000$ a $9 \$ 999$ & 528 & 53,8 & $2: 369 \$ 334$ & 7,5 \\
\hline $1731-1752$ & De $10 \$ 000$ a $49 \$ 999$ & 286 & 29,1 & $6: 130 \$ 122$ & 19,4 \\
\hline $1731-1752$ & De $50 \$ 000$ a $99 \$ 999$ & 65 & 6,6 & $4: 202 \$ 661$ & 13,3 \\
\hline $1731-1752$ & De $100 \$ 000$ a $999 \$ 999$ & 64 & 6,6 & $16 \$ 579 \$ 369$ & 52 \\
\hline $1731-1752$ & Acima de $1: 000 \$ 000$ & 2 & 0,2 & $2: 331 \$ 400$ & 7,3 \\
\hline Total & $\mathbf{3 1 : 6 4 2 \$ 3 1 6}$ & $\mathbf{9 8 3}$ & Aprox. $\mathbf{1 0 0}$ & $\mathbf{3 1 : 6 4 2 \$ 3 1 6}$ & Aprox. 100 \\
\hline
\end{tabular}




\section{Tabela 3}

Relação percentual entre os processos e os montantes das dívidas - 1731-1740

\begin{tabular}{|l|l|r|r|r|r|}
\hline \multicolumn{1}{|c|}{ Período } & \multicolumn{1}{|c|}{$\begin{array}{c}\text { Intervalos de valor } \\
\text { em réis }\end{array}$} & $\begin{array}{c}\text { Número } \\
\text { de } \\
\text { proces- } \\
\text { sos por } \\
\text { dívidas }\end{array}$ & $\begin{array}{c}\text { Percentual } \\
\text { aprox. dos } \\
\text { processos }\end{array}$ & $\begin{array}{c}\text { Mon- } \\
\text { tantes das } \\
\text { dívidas em } \\
\text { réis }\end{array}$ & $\begin{array}{r}\text { Percentual } \\
\text { aprox. dos } \\
\text { montantes }\end{array}$ \\
\hline $1731-1740$ & De $0 \$ 100$ a $0 \$ 999$ & 11 & 4,2 & $8 \$ 100$ & 0,14 \\
\hline $1731-1740$ & De $1 \$ 000$ a $9 \$ 999$ & 142 & 53,6 & $582 \$ 949$ & 9,9 \\
\hline $1731-1740$ & De $10 \$ 000$ a $49 \$ 999$ & 88 & 33,2 & $1: 852 \$ 058$ & 31,5 \\
\hline $1731-1740$ & De $50 \$ 000$ a $99 \$ 999$ & 11 & 4,2 & $773 \$ 500$ & 13,2 \\
\hline $1731-1740$ & De $100 \$ 000$ a $999 \$ 999$ & 13 & 5 & $2: 647 \$ 577$ & 45 \\
\hline $1731-1740$ & Acima de $1: 000 \$ 000$ & - & - & & - \\
\hline Total & $\mathbf{5 : 8 7 0 \$ 1 8 4}$ & $\mathbf{2 6 5}$ & $\begin{array}{c}\text { Aprox. } \\
\mathbf{1 0 0} \%\end{array}$ & $\mathbf{5 : 8 7 0 \$ 1 8 4}$ & $\begin{array}{r}\text { Aprox. } \\
\mathbf{1 0 0} \%\end{array}$ \\
\hline
\end{tabular}

\section{Tabela 4}

Relação percentual entre os processos e os montantes das dívidas (1741-1752)

\begin{tabular}{|l|l|c|c|c|c|}
\hline \multicolumn{1}{|c|}{ Período } & \multicolumn{1}{|c|}{$\begin{array}{c}\text { Intervalos de valor } \\
\text { em réis }\end{array}$} & $\begin{array}{c}\text { Número } \\
\text { de } \\
\text { proces- } \\
\text { sos por } \\
\text { dívidas }\end{array}$ & $\begin{array}{c}\text { Percentual } \\
\text { aprox. dos } \\
\text { processos }\end{array}$ & $\begin{array}{c}\text { Montantes } \\
\text { das dívidas } \\
\text { em réis }\end{array}$ & $\begin{array}{c}\text { Percentual } \\
\text { aprox. dos } \\
\text { montantes }\end{array}$ \\
\hline $1741-1752$ & De $0 \$ 100$ a $0 \$ 999$ & 27 & 3,8 & $15 \$ 330$ & 0,06 \\
\hline $1741-1752$ & De $1 \$ 000$ a $9 \$ 999$ & 386 & 53,7 & $1: 786 \$ 385$ & 6,9 \\
\hline $1741-1752$ & De $10 \$ 000$ a $49 \$ 999$ & 198 & 27,5 & $4: 278 \$ 064$ & 16,6 \\
\hline $1741-1752$ & De $50 \$ 000$ a $99 \$ 999$ & 54 & 7,5 & $3: 429 \$ 161$ & 13,3 \\
\hline $1741-1752$ & De $100 \$ 000$ a $999 \$ 999$ & 51 & 7,1 & $13: 931 \$ 792$ & 54 \\
\hline $1741-1752$ & Acima de $1: 000 \$ 000$ & 2 & 0,28 & $2: 331 \$ 400$ & 9 \\
\hline Total & $\mathbf{2 5 : 7 7 2 \$ 1 3 2}$ & $\mathbf{7 1 8}$ & Aprox. 100 & $\mathbf{2 5 : 7 7 2 \$ 1 3 2}$ & $\begin{array}{c}\text { Aprox. } \\
\mathbf{1 0 0} \%\end{array}$ \\
\hline
\end{tabular}


A maioria dos processos por dívidas em réis $(58,3 \%)$ teve valores que giraram entre $1 \$ 000$ e $9 \$ 999$ réis, ou seja, valores relativamente modestos que representaram apenas $7,5 \%$ do montante total cobrado. O percentual de pequenas quantias cobradas nessa documentação aponta para o percentual da população local que sofria com a escassez material. Os dados coletados nos recenseamentos realizados entre 1765 e 1767 na Capitania de São Paulo mostram que $54 \%$ das famílias ou $49,93 \%$ da população foram catalogadas na categoria "nada possuem". ${ }^{21}$

O caso de Manoel dos Santos Cardoso pode exemplificar a situação de muitos curitibanos no século XVIII. Em 14 de outubro de 1750, justificou seu pedido de isenção do cargo de procurador por ser pobre, pois seu rendimento era tão módico "que apenas chega para o seu sustento e um mui limitado vestir como se tem visto no seu moderado trato". ${ }^{22}$ Uma carta do morgado de Mateus ao conde de Oeiras, datada de 13 de dezembro de 1766, pinta um quadro de pobreza na região do qual escapam apenas "alguns dos filhos do Reino que traficam em pequeno negócio de panos, e sedas, e outras miudezas pela maior parte fazendas estrangeiras: aqueles tropeiros que negociam em animais de Curitiba, e Viamão; alguns Paulistas que tem umas limitadas lavras, em que faíscam o ouro o mais vive miseravelmente."23

A comparação, na tabela 2, dos dados relativos às dívidas de $1 \$ 000$ a $9 \$ 999$ réis com os dados relativos às dívidas de $100 \$ 000$ a $999 \$ 999$ réis permite perceber situações diametralmente opostas. O intervalo de $1 \$ 000$ a $9 \$ 999$ réis corresponde a $53,8 \%$ dos processos, mas soma apenas $7,5 \%$ do montante total cobrado. Já o intervalo de $100 \$ 000$ a $999 \$ 999$ réis corresponde a somente 6,6\% dos processos, mas soma $52 \%$ do montante total cobrado. Essa proporcionalidade é mantida mesmo se comparamos os períodos separadamente conforme as tabelas 3 e 4 .

No primeiro período - 1731-1740 - houve a cobrança de somente 13 dívidas entre $100 \$ 000$ e $999 \$ 999$ réis (5\% do total), que somaram 2:647\$577, ou seja $45 \%$ do montante total de 5:870\$184. No período de 1741-1752, o montante total foi de 25:772\$132, ou seja, quase quintuplicou em relação à década de 1731-1740. No entanto, a proporção de concentração de riqueza se manteve

\footnotetext{
${ }^{21}$ CANABRAVA, Alice Piffer. Decadência e riqueza. Revista de História. São Paulo, v. 50, n. 100, 1974, p. 342.

${ }^{22}$ BAMC, v. XIII, p. 25.

${ }^{23}$ Documentos interessantes para a história e costumes de São Paulo, v. 73, p. 92.
} 
muito parecida, pois apenas 51 dívidas $(7,1 \%)$ representaram um montante de 13:931\$792 ou 54\% do montante total do período 1741-1752. A partir desses dados, é possível afirmar que as relações creditícias no século XVIII apontam para a permanência da concentração de riqueza.

\section{A atuação dos prestamistas no mercado de crédito local}

Entre 1731 e 1752, compareceram perante os juizes ordinários 355 autores de processos. Destes, 275 (78\%) tiveram seus requerimentos claramente motivados por demandas creditícias, ou seja, eram prestamistas e estavam cobrando suas dívidas ativas. Dos 80 autores restantes, 35 fizeram requerimentos que não explicitam claramente o conteúdo da demanda, ou seja, requerimentos que falam em libelos, cartas de editos, agravos, sentenças, despachos, composições etc., que podem estar ligados a qualquer tipo de demanda, inclusive as creditícias. Os 45 autores restantes tiveram suas demandas claramente demarcadas como requerimentos de liberdade, coimas, esponsais, demarcação de terras, despejos etc.

Dos 275 autores ligados às demandas creditícias, apenas sete cobraram valores acima de 1:000\$000 e, destes, apenas um cobrou um montante acima de 2:000\$000. Estes homens representam pouco mais de 2\% dos credores, no entanto, eles foram responsáveis pela cobrança de $25 \%$ de todo o montante cobrado no período. Dentre estes seis grandes prestamistas, encontramos algumas pessoas que tiveram atuação central na vida social, política e econômica da vila de Curitiba no século XVIII.

O capitão Miguel Rodrigues Ribas apareceu como autor em quarenta processos, dos quais trinta relativos à cobrança de dívidas, cujo montante total declarado foi de 1:001\$270. O montante das dívidas cobradas pelo capitão era seguramente maior, pois, dos trinta processos em que esteve envolvido, treze não revelaram o valor cobrado. Cerca de $62 \%$ desse montante $(625 \$ 280)$ é representado por apenas $18 \%$ das dívidas valoradas (três dívidas de valores acima de 100\$000). As restantes dívidas, cujos valores variaram entre $2 \$ 800$ e $99 \$ 860$, somam juntas os restantes $375 \$ 990$. Isto indica que a concentração de riqueza também tende a se reproduzir em relação aos prestamistas e seus devedores, pois a análise do padrão de cobrança de outros prestamistas aponta na mesma direção.

Houve também quatro processos envolvendo a penhora de terras dos herdeiros de Izabel Luis Tigre (possivelmente para quitação de dívidas contraídas pela falecida ou por seu marido antes dela) e um processo cujo réu era seu 
sócio em umas lavras, João Simões da Costa. É ainda digno de nota que 65\% das cobranças (22 dívidas) se concentraram nos anos de 1739 e 1740, os outros $35 \%$ ficaram espalhados entre 1733 e 1750. Curiosamente, nestes anos, Miguel Rodrigues Ribas não exerceu nenhum cargo camarário. Somente a partir de 1741 ele iniciou uma série de quatro gestões como juiz até 1751. É possível que sua vacância camarária tenha dado ao autor melhores condições para dedicar-se aos seus interesses pessoais.

Miguel Rodrigues Ribas era um autêntico membro da elite local de Curitiba, pois tinha longa experiência no exercício camarário. Foi almotacé por quatro vezes na década de 1730. A documentação se refere a ele como alguém que zelava pelo "bem comum". Foi juiz árbitro em 1748 e juiz ordinário por seis vezes, em 1729, 1741, 1747, 1749, 1751 e 1755. Está entre os que desempenharam essa função por mais vezes no período estudado. Em 13 de junho de 1730, os oficiais da Câmara nomearam-no como tesoureiro do cofre dos órfãos, pois era "morador nesta vila, homem de negócio, boa consciência e sobretudo abonado". ${ }^{24}$ Em 2 de janeiro de 1744, seu nome saiu no pelouro para exercer o cargo de tesoureiro do cofre dos órfãos no triênio 1744 - 1746, mas em 21 de julho do mesmo ano apresentou à Câmara um mandado do ouvidor que o isentava dessa função. Foi juiz de órfãos no biênio 1753 - 1754.

Além de sua assídua atuação política e administrativa, Miguel Rodrigues Ribas foi notório homem de negócio da vila, tido e havido como detentor de grande fortuna e cabedal. ${ }^{25}$ Esteve envolvido em negócios de lavras de ouro, fazendas secas e comércio de tropas. Em 29 de outubro de 1730, "apresentou Miguel Rodrigues Ribas homem mercador de fazendas secas, 81 oitavas e meia de ouro em pó que tanto lhe pagaram os mineiros do Arraial Grande de fazendas que lhe compraram". ${ }^{26}$ Entre 1730 e 1735 , foi quem mais vezes e maiores quantidades de ouro registrou para ser quintado na casa de fundição de Paranaguá, pois das 9.526 oitavas de ouro registradas no período, nada menos que 4.469 (47\%) eram dele. ${ }^{27}$ Apenas essas oitavas de ouro representavam 5:362\$800, o

\footnotetext{
${ }^{24}$ BAMC, v. XI, p. 75.

${ }^{25}$ Ver STANCZYK FILHO, Milton. "Os declaro, e instituo, e nomeyo, por meus legitimos e oniverçais erdeiros": Família e transmissão de bens nos sertões de Curitiba, 1725-1801. In: XIV Encontro Nacional de Estudos Populacionais. São Paulo: Abep, 2004.http://www.abep. nepo.unicamp.br/site_eventos_abep/PDF/ABEP2004_441.pdf.

${ }^{26}$ BAMC, v. X, p. 86.

${ }^{27}$ BCMC. Livros de registro do ouro do juiz ordinário, $1730-1735$.
} 
que o coloca entre os homens mais ricos, senão o mais rico da vila de Curitiba. O concelho da vila confiava tanto em Miguel Rodrigues Ribas que, em 6 de fevereiro de 1736, depositou em suas mãos os $100 \$ 000$ destinados à reforma da igreja matriz.

Miguel Rodrigues Ribas mantinha relações comerciais diretas com outras partes da colônia. Em 1736, pediu autorização à Câmara de Curitiba para levar duzentos cavalos para São Paulo. ${ }^{28}$ Sua rede de influência era bastante extensa. Em 14 de junho de 1733, ele nomeou diversos procuradores para cuidarem de seus interesses em Curitiba, Paranaguá, Santos, São Paulo, Itu, Rio de Janeiro, Cidade da Bahia, Pernambuco e Lisboa. A procuração repete o linguajar de praxe dando poderes para:

procurar, e alegar e defender e mostrar todo o seu direito e justiça em todas as suas causas e demandas movidas e por mover em que seja autor ou réu e poderão arrecadar sua fazenda a dinheiro, ouro, prata, açúcar, escravos, encomendas, carregações e suas procedidas dividas que the devam dinheiro de cofre dos ausentes e dos almoxarifados e finalmente tudo o mais que se achar lhe é pertencente por qualquer via, título, razão e de documento que seja pedindo e tomando contas a quem lhas deva dar ajustando-as e liquidando-as e fazendo-as, e seu líquido receberem e de tudo quanto arrecadarem e receberem dar quitações públicas ou rasas de maneira que pedidas lhe forem, e a seus devedores citar e de mandar perante todas e quaisquer justiças. ${ }^{29}$

A maior parte das procurações documentadas para o período entre as décadas de 1730 e 1750 nomeia procuradores em Curitiba e Paranaguá, algumas poucas ampliam seus procuradores para outras localidades como Laguna, São Paulo, Sorocaba e Itu. A procuração de Miguel Rodrigues Ribas é a mais abrangente de todas e, assim, podemos inferir que, a partir de Curitiba, estava envolvido em uma rede de negócios que alcançava as principais praças mercantis da colônia e até a capital do Império. É interessante notar ainda que seus procuradores na Bahia, Joseph Rodrigues Ribas e Antonio Rodrigues Ribas, em Pernambuco, Simão Ribeiro Ribas, e em Lisboa, Miguel Ribeiro Ribas, têm nomes que parecem guardar parentesco com o potentado curitibano. Este último tem o mesmo nome de seu filho nascido em 1723 que, na data da procuração, contava a idade

\footnotetext{
${ }_{28}^{28}$ BCMC. Livro de avulsos, v. 2, fl. 10.

${ }^{29}$ Primeiro Cartório de Notas de Curitiba (Cartório Giovanetti). Livro de notas, v. 5, fl. 66v e 67. Cópia digital do acervo do Centro de Documentação de Pesquisa de História dos Domínios Portugueses - Cedope, UFPR.
} 
de apenas dez anos. É possível que sejam seus parentes, mas infelizmente a documentação disponível não permite maiores certezas. No entanto, se de fato forem aparentados, é plausível que Miguel Rodrigues Ribas fosse o representante local de uma família de negociantes do Império Português. Seja como for, os negócios e os contatos de Miguel Rodrigues Ribas parecem apontar para a sua participação - mesmo que de forma minoritária e como um representante local - naquilo que João Fragoso chamou de mercadores e fortunas imperiais.

Por certo, estas rotas ultramarinas criaram - além dos oficiais agraciados com mercês do tipo liberdades da Índia - os seus próprios personagens, no caso, os negociantes com grande cabedal e capazes de estabelecer redes de contato: sócios, parceiros circunstanciais, caixeiros etc., nas diferentes partes do ultramar. Por conseguinte, o império luso seria também o espaço para a existência de um grupo de empresários, cujos empreendimentos e fortunas se fizeram, literalmente, nos vários mares onde os portugueses, em diferentes graus, estavam presentes. ${ }^{30}$

Miguel Rodrigues Ribas foi o exemplo muito bem acabado do proeminente homem colonial que reunia em si cabedal e governo, ou seja, fortuna e autoridade. Ele exerceu um papel central na vida política e econômica da vila entre as décadas de 1730 e 1750. Como vimos, seu nome aparece diversas vezes como credor de dívidas nos termos de audiências dos juízes ordinários. Parece ter sido um dos entroncamentos da rede de endividamentos que permeava a economia da vila. Seu percurso como homem público e homem de negócio parecem entrecruzar-se. Seu papel no fornecimento de crédito pode ter influenciado no apoio recebido da elite local, assim como sua militância camarária certamente deu-lhe vantagens no processo de consolidação de sua posição de "homem de negócio, boa consciência e sobretudo abonado" da vila de Curitiba. Seu poder, prestígio e fortuna foram herdados por seu filho Lourenço Ribeiro de Andrade, que foi o único membro da Câmara até o início da década de 1750 a ostentar o título de doutor pela Universidade de Coimbra. Lourenço Ribeiro de Andrade desempenhou o papel de juiz ordinário em 1750 e tornou-se capitão mor da vila na segunda metade do Setecentos. Os seus descendentes formaram um dos principais grupos familiares oligárquicos que estiveram envolvidos em conflitos de poder na vila. Assim foram descritos em 1804:

${ }^{30}$ FRAGOSO, João. Mercadores e negociantes imperiais: um ensaio sobre a economia do Império Português (séculos XVI e XIX). História: questões \& debates. Curitiba, v. 19, n. 36, 2002, p. $110-111$. 
Estas antecipaçoins me obrigarão a entrar circunstanciadam. ${ }^{\text {te }}$ na inteligencia da Origem mutora destas desavenças; E me fica Sendo Constante, que ellas não deixão de ter principio nas Influencias do dito Ten. ${ }^{\text {te }}$ Coronel [Francisco de Paula Ribas] pella Acendencia, que tem na Autoridade do Cap. ${ }^{\text {mor }}$ Seo Irmão [Antonio Ribeiro de Andrade], e da mesma Camera, em que São Juizes Seo Cunhado João Antonio Pinto, Seo Tio Antonio Joze de Andrade; e Camaristas o filho do $\mathrm{m} .{ }^{\mathrm{mo}} \mathrm{Cap} .{ }^{\text {mor }}$ Joaquim Mariano, e outros do Seo partido. ${ }^{31}$

Miguel Gonçalves de Lima foi outro dos grandes prestamistas de Curitiba. Foi quem cobrou o maior montante em todo o período analisado (2:130\$640). Ele executou judicialmente 28 diferentes pessoas para as quais concedeu 36 créditos, dos quais apenas dois não tiveram seus valores estipulados pela documentação. Dos 34 créditos com valor conhecido, apenas oito ultrapassavam os 100\$000, que somaram juntos 1:695\$650, ou seja, $22 \%$ dos créditos representaram $80 \%$ do montante total cobrado. Entre 1732 e 1735, ele registrou 1.054 1/2 oitavas de ouro para serem quintadas em Paranaguá, as quais valiam 1:265\$200. Ele também tinha ligações com João Simões da Costa, sócio de Miguel Rodrigues Ribas em umas lavras. Além de sua atuação no mercado de crédito local, também exerceu cargos camarários: almotacé em 1741 e 1742 e vereador em 1743.

Mais um prestamista de peso foi Sebastião dos Santos Pereira, que citou em juízo 33 réus, tentando cobrar 37 dívidas, que somavam um montante de 1:406\$490. Foi testamenteiro do comerciante Francisco Baptista e também atuou como advogado (procurador) defendendo os interesses de terceiros em dez processos perante o Juízo Ordinário. Sebastião dos Santos atuou em cinco ações como procurador de João da Cruz Borges, a quem representava em alguns negócios. Em 14 de abril de 1739, Manoel Pinto Ribeiro passou um recibo para Sebastião dos Santos Pereira, o qual reconhecia que lhe devia 255\$000, valor relativo à compra de dois moleques (Francisco e Paulo) "do gentio da guiné", que pertenciam a João da Cruz Borges. Em 4 de setembro de 1741, Sebastião dos Santos afirmou ter recebido $135 \$ 000$ como pagamento de Francisco e ainda ficou para receber os restantes $120 \$ 000$ relativos ao preço de Paulo, que o autor cobrou perante o juiz ordinário somente em 16 de novembro de $1744 .^{32}$ Sebastião dos Santos atuou nesse processo como intermediário de João da Cruz Borges na venda dos escravos e na cobrança da dívida resultante. Sebastião dos Santos Pereira era um autêntico representante da nobreza da terra. Atuou

\footnotetext{
$\overline{31}$ Arquivo do Estado de São Paulo. C00261. Manuscritos militares Paranaguá, 1742-1822.

${ }^{32}$ Arquivo Público do Paraná. JP 800, cx. 45.
} 
como procurador da Câmara em 1729, juiz ordinário em 1733 e almotacé em 1731, 1732 e 1734 .

É interessante notar que a grande maioria os autores de processos de cobrança de créditos que requereram em mais de um processo junto ao Juízo Ordinário tinham relações creditícias com o maior número de pessoas possíveis, pois os réus citados eram os mais variados. Por exemplo, Miguel Rodrigues Ribas requereu em 40 processos e citou 38 diferentes réus. Miguel Gonçalves Lima cobrou 36 créditos e citou 28 réus, Sebastião dos Santos Pereira cobrou 37 créditos de 33 diferentes réus. Este era o padrão de cobranças, ou seja, os prestamistas estabeleciam relações de crédito com o maior número possível de pessoas, seja para estabelecer relações comerciais e pessoais mais longas e capilarizadas, seja para diversificar a concessão de crédito e minimizar os riscos de inadimplência.

O tenente Manoel Alves Fontes cobrou nove dívidas entre 1731 e 1751. No entanto, apenas duas apresentaram os valores que somaram um total de $219 \$ 120$. Se tivéssemos acesso a todos os valores das outras sete dívidas, seguramente apareceria como um dos grandes negociantes de crédito da vila. Uma procuração passada por ele, em 7 de julho de 1742, aponta nesse sentido, haja vista que nomeou quatro procuradores em Curitiba, quatro em Paranaguá, três em Santos, quatro em São Paulo, quatro no Rio de Janeiro e três na Cidade da Bahia (Salvador). ${ }^{33}$ Seus procuradores indicam que, a partir de Curitiba, mantinha interesses em uma ampla área da colônia.

Fontes foi vereador em 1751, no entanto, em 1755 ele fez uma petição à Câmara da vila de Curitiba na qual pedia dispensa do exercício do cargo para o qual havia sido eleito, pois estava indo em uma "viagem para o Rio de Janeiro alcançar uma boiada de 400 bois, que leva para dispor na dita cidade (...) e de não ir lhe resulta toda ruína de seus bens por ter comprado fiada a dita boiada". ${ }^{34}$

A documentação demonstra que membros da elite política da vila de Curitiba eram negociantes de tropa e mantinham ligações comerciais diretas com São Paulo, Minas Gerais e Rio de Janeiro. Manoel Alves Fontes deixa claro que comprou a boiada fiada, contraindo dívidas para realizar lucros no Rio de Janeiro. É possível que tenha trocado a boiada por outros produtos que, em Curitiba, serviriam para quitar as dívidas contraídas ou repassados como adiantamento

\footnotetext{
${ }^{33}$ Primeiro Cartório de Notas de Curitiba (Cartório Giovanetti). Livro de notas, v. 9, fl. 44. Cópia digitalizada do acervo do Cedope-UFPR.

${ }^{34}$ BCMC. Livro de avulsos, v. 1, fl. 1.
} 
para outros comerciantes, alimentando o ciclo adiantamento / endividamento típico da economia colonial. Um documento, citado por Helen Osório, atesta o costume de negociar fiado: "neste continente nunca se fazem vendas de bens alguns com dinheiro à vista e só fiados com espera de longos anos de sorte que se vá pagando com o produto dos gados da mesma fazenda." ${ }^{35}$

A documentação dos arquivos locais fornece diversos exemplos de curitibanos envolvidos nas remessas de gado muar, cavalar e vacum às praças de São Paulo, Minas Gerais e Rio de Janeiro. ${ }^{36} \mathrm{O}$ dinamismo desse comércio se devia ao fato de o Rio de Janeiro ter-se tornado, ao longo do século XVIII, "um ponto de encontro de diferentes rotas dos diversos mercados regionais internos da América lusa e das acumulações deles derivadas; um porto fundamental para o comércio externo com o reino e as demais conquistas; e, em particular, um entreposto na redistribuição interna na América portuguesa de produtos vindos de Portugal e de outras partes do império luso." ${ }^{37}$

Ilana Blaj defendeu a noção de que São Paulo vinha sofrendo um processo de mercantilização desde o século XVII e que sua rede mercantil se espraiou para o restante da capitania, interligando-se com outras regiões da colônia a partir do século XVIII. A autora entende que o comércio de gado entre o sul e as minas teve papel fundamental nesse processo. ${ }^{38}$ De fato, a abundância de gado nos campos de Curitiba chamou a atenção dos cronistas coloniais já no início do século XVIII: “As vilas de São Paulo matam as reses que tem em suas fazendas, que não são muito grandes, e só nos campos de Curitiba vai crescendo e multiplicando cada vez mais o gado". ${ }^{39} \mathrm{Na}$ segunda metade da década de 1760 , o governador da Capitania de São Paulo, o morgado de Mateus, se referia ao comércio realizado pela rota dos muares como o "mais sólido", "mais limpo" e o "maior que tem havido nesta capitania". O negócio de tropa estava dando grandes lucros tanto à Fazenda Real como aos que nele se envolviam. Em 1766,

${ }^{35}$ OSÓRIO. Comerciantes do Rio Grande, op. cit., p. 128.

${ }^{36}$ Vereador em 1750, em 1756, o tenente João Batista Dinis foi eleito juiz de órfãos de barrete em Curitiba, mas pediu isenção do cargo, pois estava de partida para o Rio de Janeiro com uma boiada onde estava devendo "para cima de três mil cruzados" e precisava "dar correspondência a seus credores". BCMC. Livro de avulsos, v. 2, fl. 48.

${ }^{37}$ FRAGOSO, João. Mercadores e negociantes imperiais, op. cit., p. 118.

${ }^{38}$ BLAJ, Ilana. A trama das tensões: O processo de mercantilização da São Paulo colonial (1681 - 1721). São Paulo: Humanitas, 2002.

${ }^{39}$ ANDREONI, João Antonio [Antonil]. Cultura e opulência do Brasil por suas drogas e minas (1711). São Paulo: Ed. Nacional, 1966, p. 309. 
passaram “pelo registro de Curitiba, 5.664 cavalos e éguas, 1.909 mulas e 2.147 rezes, que se avaliam em 56:000\$000 aproximadamente." 40

O negócio de tropas realizado pelos curitibanos tornou-se um mecanismo potencializador das redes de endividamento da própria localidade e desta com outras regiões da colônia. Este processo se ramificava a partir das grandes praças portuárias para as pequenas vilas do sertão, como Curitiba, que, a partir da década de 1730, tornou-se um importante elo para o comércio de gado entre o Continente de São Pedro, São Paulo, Minas Gerais e Rio de Janeiro. O continente de Curitiba inseriu-se, como uma ramificação, na rede de endividamento e crédito que se estendia por todo o centro-sul da colônia. O mercado de crédito da vila era controlado por um pequeno grupo de pessoas que, além dos recursos econômicos, tinha acesso privilegiado aos cargos camarários e vice versa, o que assinala uma característica típica da economia do Antigo Regime lusitano.

Recebido: maio/2009 - Aprovado: setembro/2009.

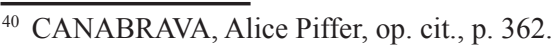

